\title{
Disbarment in the Federal Courts
}

Recent political scandals involving lawyers have stimulated interest in professional discipline. ${ }^{1}$ Although the bar and the judiciary long have attempted to regulate the conduct of attorneys, ${ }^{2}$ attorney discipline remains an unsolved problem. Reform efforts have focused largely on discipline in state rather than federal courts. ${ }^{3}$ This Note examines the nature of federal disbarment and the disciplinary rules currently in force. ${ }^{4}$ It argues that the federal courts ${ }^{5}$ should take a more active role in attorney discipline and that Congress should authorize the Supreme Court to promulgate uniform rules of discipline.

\section{The Derivative Nature of Federal Disbarment}

For the most part, federal discipline currently follows state discipline. A federal court normally disciplines an attorney after a disciplinary proceeding by the state court, ${ }^{,}$usually imposing the same

1. See, e.g., Aronson, Professional Responsibility: Education and Enforcement, 51 WASH. L. REv. 273 (1976). On attorney disciplinary proceedings and sanctions stemming from the Watergate scandals, see, e.g., Comment, 1972 Pennsylvania Supreme Court Rules of Disciplinary Enforcement: Relieving the Uncertainties of Marginal Attorney Crimes, 79 Dick. L. REv. 588.89 n.3 (1975); Note, In re Krogh and Attorney Discipline in Washington, 12 WillaMetTE L.J. 374 (1976) (discussing Washington Supreme Court's disbarment of Egil Krogh, Jr. for felony arising out of Watergate scandal); Association of the Bar of the City of New York, Committee on Grievances, Annual Report 1973-74, pt. II (on file with Yale Law Journal).

2. See, e.g., ABA Code of Professional Responsinility (1974). For an historical discussion of the Code of Professional Responsibility and its predecessor, the Canons of Professional Ethics, see Note, Disbarment: A Case for Reform, 17 N.Y.L.F. 792, 793.97 (1971).

3. See aba Special Committee on Evaluation of Disciplinary Enforcement, ProbI.LMS AND Recommendations in DisciplinaRy ENForcement (1970) [hereinafter cited as ABA RrPorT] (discussing deficiencies in state disciplinary procedures). Pennsylvania, for cxample, recently reformed its disciplinary process. Pennsylvania Bar Association, Code of Professional Responsibility, Rules of Disciplinary Enforcement, and Disciplinary Bo.sn Rules ANd Procedures (1974). For a state-by-state account of discipline reform, see ABA Special Committee on National Coordination of Disciplinary Enforcement, Recommendation and Report 3-20 (Aug. 1972) (on file with Yale Law Journal).

4. Federal and state courts have wide latitude in their choice of sanctions. The available sanctions include (in order of increasing severity) reprimand, censure, fine, suspension, and disbarment. This Note discusses disbarment, but its conclusions apply equally to the use of lesser disciplinary sanctions.

5. This Note focuses primarily on disbarment in the United States district courts. Most attorncy contact with federal courts occurs at the district court level, with discipline normally handled by that court. See, e.g., In re Carroll, 416 F.2d 585, 587 (10th Cir. 1969), cert. denied, 396 U.S. 1011 (1970). However, the higher federal courts have promulgated disciplinary rules. E.g., U.S. SUP. CT. R. 8 (covering attorney disbarment); FED. R. APP. P. $46(b)$ (uniform rule covering suspension or disbarment).

G. In re Abrams, 385 F. Supp. 1210, 1214 (D.N.J. 1974), rev'd, 521 F.2d 1094 (3d Cir.), cert. denied, 423 U.S. 1038 (1975) ("[D]isciplinary proceedings in our courts ofttimes follow upon the coattails of extensive records and hearings in the state courts . . . . [O]ur disciplinary proceedings are ... derivative because based in part on a previously compiled state record.") 
sanction as the state court. ${ }^{7}$ However, the district courts act somewhat more independently when misconduct arises in the federal sphere ${ }^{8}$ or when the prior state proceeding was so deficient that notions of equity or requirements of procedural due process preclude following it. ${ }^{9}$ This deference to state proceedings reflects, in part, the derivative nature of attorney admission to federal practice. ${ }^{10}$ It also stems from the view that federal practice is limited in extent ${ }^{11}$ and that principles of comity override benefits which might flow were federal discipline not simply a by-product of state discipline. From a historical perspective, deference is understandable because federal courts once did not occupy the prominent place they do today. ${ }^{12}$ Yet today abdication of responsibility with respect to discipline is no longer justifiable.

The derivative nature of federal disbarment has impeded the development of effective disciplinary rules by the federal district courts. There are no uniform federal procedures for disbarment and suspension of attorneys. ${ }^{13}$ Each district court is authorized to develop

7. In his concurrence in In re Abrams. 521 F.2d 1094, 1106 (3d Cir.), cert. denied, 423 U.S. 1038 (1975), Judge Rosenn observed:

Sixty-nine district courts responded to a survey asking whether they ever had deviated from disciplinary actions taken by the courts of their states. One district court . . . responded that they had a rule permitting disparate discipline .... Only three other district courts cited instances of deriating from the action of their state courts.

8. See In re Abrams, 385 F. Supp. 1210, 1212 (D.N.J. 1974), rev'd, 521 F.2d 1094 (3d Cir.), cert. denied, 423 U.S. 1038 (1975). See In re Claiborne, 119 F.2d 647, 650 (1st Cir. 1941) (district judge on own motion properly directed investigation as result of events (luring federal litigation).

9. See, e.g., In re Ruffalo, 390 U.S. 544 (1968); Theard v. United States, 354 U.S. 278 (1957); Selling v. Radford, 243 U.S. 46, 51 (1917) (dictum). A finding that the state disbarment cannot be followed does not preclude a federal court from conducting its own inquiry. E.g., In re Bennethum, $196 \mathrm{~F}$. Supp. 541, 545 (D. Del. 1961), ordering trial de novo in 205 F. Supp. 821 (D. Del. 1962) (state disbarment proceeding provided inadequate notice; district court appointed committee to prefer charges in federal court and disbarred attorney following trial de noro).

10. An attorney may be admitted to federal district court following his admission to the highest court of the state within which the federal court sits. Sec, e.g., W.D.N.Y. GEN. R. 2(a); E.D. PA. R. 9(a); W.D. TEx. R. 2(a). For criticism of this method of admission, see Wilkey, $A$ Bar Examination for Federal Courts, 61 A.B.A.J. 1091 (1975).

11. See, e.g., In re Abrams, 385 F. Supp. 1210, 1212 (D.N.J. 1974), rev'd, 521 F.2d 1094 (3d Cir.), cert. denied, 423 U.S. 1038 (1975):

If the ... discipline [of a state] be more severe than ours, it will likely control the practical impact because the ability to practice before this court would have little meaning without the ability to practice law in New Jersey. If this Court's discipline be more severe, the practical impact will be lessened considerably by the lawyer"s ability to practice law in New Jersey although not in this court.

12. See Adminisrrative Office of United States Courts, Annual Report 200 (197.t) (citing $110 \%$ increase orer 1940 in cases filed in federal district courts and $233 \%$ increase in cases pending); H. Friendly, Federal JuRisuiction: A Generil View 3-4, 15-54 (1973) (discussing "cxplosion" in fecleral court litigation). See generally, Hart, The Relalions Between State and Federal Law, 54 ColuM. L. REv. 489, 491-506 (1954) (discussion of the interstitial nature of federal courts).

13. In $r e$ Echcles, 430 F.2d 347,350 (7th Cir. 1970) ("In the federal system there is no established uniform procedure for suspension and disbarment proceedings in the district courts; the matter is left to the individual judicial districts.") 
its own disciplinary mechanism under Rule 83 of the Federal Rules of Civil Procedure $e^{14}$ and pursuant to its own inherent authority to regulate the attorneys who appear before it. ${ }^{15}$

Despite this authority, most federal judicial districts handle discipline on an ad hoc basis. Indeed, some federal districts have no formal disciplinary rules at all. ${ }^{16}$ The others have adopted varying types of disciplinary rules. The most prevalent requires an attorney disbarred in another court to "show cause" why he should not be disciplined by the federal court. ${ }^{17}$ Two other rules are fairly common: the first requires a lawyer convicted of a felony to show cause why he should not be disbarred; ${ }^{1 s}$ the second merely states that an attorney may be disbarred for "good cause."19

Those district courts which have promulgated substantive criteria for disbarment or suspension from practice have developed disparate standards. ${ }^{20}$ The courts also have accorded varying procedural protections. ${ }^{21}$ Only a few districts require that other courts receive notifica-

14. Fed. R. Civ. P. 83 provides:

Each district court . . may from time to time make and amend rules governing its practice not inconsistent with these rules. ... In all cases not provided for by rule, the district courts may regulate their practice in any manner not inconsistent with these rules.

For discussions of the scope of Rule 83, sce Note, Rule 83 and the Local Federal Rules, 67 Colum. L. Rev. 1251 (1967); Comment, The Local Rules of Civil Procedure in the Federal District Courts-A Survey, 1966 Duke L.J. 1011. It is questionable whether Rule 83 governs promulgation of disciplinary rules by the district courts, as discipline may be outside the scope of the "practice" of the district courts. See TAN 69 infra. Even so, the district courts may adopt such rules under their inherent power to regulate attorneys who practice before them.

15. Ex parte Garland, 7I U.S. (4 Wall.) 333, 378-79 (1866); Ex parte Burr, 22 U.S. (9 Wheat.) 529, 530-31 (1824); In re Patterson, 176 F.2d 966, 967 n.1 (9th Cir. 1949).

16. The following districts have no disciplinary rules: M.D. Ala.; S.D. Ala.; M.D. Ga.; S.D. Ga.; E.D. Ky.; N.D. Miss.; S.D. Miss.; W.D. N.C.; M.D. Tenn.; E.D. Tex.; N.D. Tex; D. Utah; D. Vt.

17. E.g., D. Conn. Civ. R. 2(d)2; D. Del. R. 25; E.D. Ill. Civ. R. 1(f); S.D.N.Y. Gen. R. 5 (d).

18. E.g., N.D. OHio R. 2(g); W.D. PA. R. 22.

19. E.g., D. Conn. Civ. R. 2(d)1; S.D. Fla. Gen. R. 16E(1); W.D. Mich. Gen. R. 4(d).

20. See, e.g., D. ME. R. 3(f) (felony conviction or conduct unbecoming an attorney, violation of Code of Professional Responsibility, willful violation of FED. R. CIv. P. 11); D. MAss. R. 5(d)(I) (conviction of crime involving moral turpitude, violation of oath of office); S.D. OHIo R. 2.4.6 (violation of Code of Professional Responsibility or judgment of mental incompetence); E.D. WASH. GEN. R. $\mathrm{l}(\mathrm{g})$ (felony conviction or misdemeanor involving moral turpitude).

21. Some districts require notice to the attorney who is the subject of the disciplinary proccedings. E.g., N.D. CAL. GeN. R. 8(e)(3). Almost half of the district rules require a hearing. E.g., N.D. IND. GeN. R. 1(e); D. KaN. R. 4(k); D. Mont. R. I(g); D.R.I. R. 4(e)(I). But two districts provide for disbarment "without notice or hearing." M.D.N.C. GEN. R. 2(f)(2) (after disbarment by state court or conviction of a felony); N.D. W. VA. GEN. R. 1.05(h) (similar provision). (These two rules may not provide due process of law. See In re Jones, 506 F.2d 527, 528 (8th Cir. 1974) (local rule providing for "ipso facto" disbarment following felony conviction did not provide adequate notice). See also note 29 infra.) A few rules provide for automatic disbarment following suspension or disbarment by another court, with an opportunity for a subsequent hearing. See, e.g., D. CoNN. Crv. R. 
tion of disbarment or suspension of an attorney. ${ }^{22}$ Only a minority have rules governing commencement of disciplinary proceedings, ${ }^{23}$ and some judges may be uncertain about how to initiate them. ${ }^{24}$

\section{The Need for Independent Exercise of Federal Disciplinary Power}

The dependence of federal discipline is neither required by the Constitution nor justified by considerations of policy. Like state courts, federal courts always have had inherent authority to control their officers. ${ }^{25}$ However, the independent disciplinary power of the federal courts is circumscribed by their reliance on prior state disciplinary action.

The power of a federal court in a disciplinary proceeding based on a prior state proceeding to impose sanctions different from those imposed by the state court was addressed first in Selling $v$. Radford. ${ }^{20}$ After his state disbarment for professional misconduct, an attorney was brought before the Supreme Court to show cause why he should not be expelled from the bar of that Court. ${ }^{27}$ The Court held that state disbarment gives rise to a presumption in federal court that the attorney lacks the required moral character to practice law and that he therefore should be disbarred. ${ }^{28}$ The presumption created by the state disbarment could be overcome by any of three conditions: (1) the state procedures denied the attorney due process of law; (2) the proof

2(d)2. Some districts provide for public hearings by order of the court or at the request of the attorney. See, e.g., N.D. CAL. GEN. R. 8(e)(3) (order of the court); N.D. ILL. GEN. R. 8(d) (consent of attorney); D. MD. GEN. R. 2A(G) (request of attorney). Two districts explicitly provide that attorneys may be represented by counsel: S.D. FLA. GLN. R. 16E(7); S.D. TEx. R. 1(I). Another procedural safeguard requires written findings of fact. See, e.g., D. Alas. Gen. R. 3(G)(6); S.D. Fla. Gen. R. 16E(8); D. Hawait R. 1(h)(6).

22. E.g., C.D. CAL. R. 1.3(e)(4) (notice to United States attorney and state bar); D.N.J. Gen. R. 7(6) (notice to New Jersey supreme court and Third Circuit); D. Mo. GrN. R. 2A(G) (notice to Maryland Court of Appeals, state bar association, and National Discipline Data Bank). The National Discipline Data Bank was established by the ABA in 1968 as a clearinghouse for disciplinary information. The Data Bank primarily serves state disciplinary bodies. See B. Agata, Report to the Federal Judicial Center on Admissions and Discipline of Attorneys in Federal District Courts 45 (1974) (on file with Yale Law Journal).

23. Twenty-three of the federal districts have rules that provide for disciplinary proceedings initiated in federal court. E.g., N.D. CAI. GEN. R. 8(e)(1); D.D.C. R. 4-3; D.N.J. R. 7(3); E.D. PA. Civ. R. 13. District court rules are collected in Fed. Locil CourT RuLes (Callaghan \& Co. 1975).

24. B. Agata, supra note 22 , at 42 . Some district courts have reported insufficient funds to prosecute disciplinary charges. Committee on Court Administration, Judicial Conference of the United States, Report 3 (Sept. 1973) (on file with Yale Law Journal).

25. See cases cited in note 15 supra.

26. 243 U.S. 46 (1917).

27. Id. at 47-48. The attorncy had been disbarred by the state supreme court for fraud in handling an estate. In re Radford, 168 Mich. 474, 134 N.W. 472 (1912).

28. 243 U.S. at 49-51. 
was patently insufficient; or (3) some other "grave reason" existed why the federal court should not disbar. ${ }^{29}$ Yet the Court also stated that the right to practice before it could not be taken away except by its own action..$^{30}$

In Theard $v$. United States, ${ }^{31}$ the Court applied Selling and reversed a federal court disbarment based solely upon a state disbarment. The attorney had been disbarred by the state court for a forgery which had occurred 19 years earlier when he was mentally disabled. After the state disbarment he was disbarred by the district court under a "show cause" rule. ${ }^{32}$ Reversing the federal disbarment, the Supreme Court found that the attorney's mental condition at the time of forgery and his satisfactory professional conduct after recovery from that condition constituted the "grave reason" required by Selling for departure from the state sanction. ${ }^{33}$ The Court emphasized the independence of the disciplinary power of the federal courts:

While a lawyer is admitted into a federal court by way of a state court, he is not automatically sent out of the federal court by the same route. The two judicial systems of courts, the state judicatures and the federal judiciary, have autonomous control over the conduct of their officers $\ldots . .^{34}$

Selling and Theard suggest that disciplinary proceedings within the federal and state systems are not linked inextricably; some circumstances require, and others permit, federal decisions to reach a different result. At the same time, these cases establish limits upon the independent power of federal courts to discipline officers in derivative proceedings. They suggest that, unless one of the Selling conditions is met, a federal court must impose the same penalty as that imposed by the prior state disciplinary action. Selling and Theard, however, did not involve an attempt by a federal court to impose a more stringent sanction.

29. Id. at 51. That a federal court cannot follow a state disbarment which denies the attorney due process of law does not mean that the state disbarment necessarily will be oserturned. In In re Ruffalo, 390 U.S. 544 (1968), the Supreme Court reversed a federal disbarment based on disbarment by the state because the state disbarment provided inadequate notice. However, the Supreme Court previously had allowed the state disbarment order to become final by denying a petition for certiorari. Ruffalo $v$. Mahoning County Bar Ass'n, 176 Ohio St. 263, 199 N.E.2d 396, cert. denied, 379 U.S. 931 (1964).

30. 243 U.S. at 48 .

31. 354 U.S. 278 (1957).

32. Id. at 281-82.

33. Id. at 282 .

34. Id. at 281 . 
In re Abrams, ${ }^{3 \overline{5}}$ recently decided by the Third Circuit, did raise this question. The case illustrates the disadvantages of derivative policing and the need for independent enforcement of attorney discipline in the federal courts. The district court disbarred an attorney ${ }^{36}$ who had helped bribe public officials and had been suspended for one year by the Supreme Court of New Jersey. ${ }^{37}$ The court of appeals began by stating that the "absolute and unfettered power of the district court to discipline lawyers [independently of the disciplinary procedures of the state courts] may be circumscribed to the extent that the district court, in imposing its disciplinary sanctions, relies upon a state's factual or legal determinations." 38 The court of appeals reversed the disbarment because the district court had substituted its own interpretation of state law for that of the New Jersey court ${ }^{39}$ and because the district court, without initiating a disciplinary action independent of the state suspension, had relied on a charge against Abrams not considered in the state proceedings. ${ }^{40}$

The Third Circuit did not reach the question of whether a showing of "grave reason" would justify departure from the milder state action if the district court had relied only on federal law and only on the

35. 521 F.2d 1094 (3d Cir.), cert. denied, 423 U.S. 1038 (1975). Abrams seems to be a case of first impression. In In re Fleck, 419 F.2d 1040 (6th Cir. 1969), cert. denied, 397 U.S. 1074 (1970), where the federal court disbarred three attorneys after the state "indefinitely suspended" them, the sanctions imposed were essentially the same. Moreover, Fleck avoided discussion of the issues explicitly raised in Abrams. In his Abrams concurrence, 521 F.2d at 1106, Judge Rosenn distinguished two other cases in which a federal court departed from a state result: In re Dreier, 258 F.2d 68 (3d Cir. 1958) (court of appeals reversed district court decision barring admission of attorney suspended and reinstated by state court); In re Mackay, 298 F. Supp. 170 (D. Alas. 1969) (district court which did not follow state suspension had appointed special master who had conducted three-day hearing).

36. 385 F. Supp. 1210, 1212 (D.N.J. 1974). Apparently, the district court was procecding under D.N.J. GEN. R. 7(2)(b) and 7(3), which authorize the court to order an attorney "[w]ho has been disbarred, suspended from practice or censured in any State, Territory, District, Commonwealth or Possession" to "show cause . . . why he should not be disciplined."

37. In re Abrams, 65 N.J. 172, 176, 179, 320 A.2d 471, 474, 475 (1974).

38. 521 F.2d at 1101 .

39. The New Jersey supreme court had distinguished In re Colsey, 63 N.J. 210, 306 A.2d 72 (1973), in which an attorney had been disbarred for payments to public officers similar to those made by Abrams. According to the New Jersey court, the attorney in Colsey had played an "active part" in the bribery scheme, whereas in Abrams the lawyer was a "co-victim" as well. $65 \mathrm{~N}$.J. at $176,320 \mathrm{~A} .2 \mathrm{~d}$ at 475 . The district court did not agrce that Colsey was distinguishable. Reversing the district court, the Third Circuit stated: "Having elected to bottom its own rational analysis on New Jerscy law, the controlling case for the district court was In re Abrams-not In re Colsey." 521 F.2d at 1103 .

40. The county ethics committee originally charged Abrams with bribery and illegal fee-splitting. 521 F.2d at 1103-04. The state court's decision to suspend him was based on the bribery charge alone. Yet the district court relied on both charges in deciding to disbar. 385 F. Supp. at 1211. 
charge considered by the state court. ${ }^{41}$ It did make clear, however, that had the district court initiated disciplinary proceedings independently, as provided for by its local rules, the lower court could have held the attorney to a higher standard than the state had without fear of reversal. ${ }^{42}$

Were state disciplinary processes effective, derivative policing might be acceptable. Unfortunately, it appears that state enforcement of attorney discipline is inadequate. ${ }^{43}$ There are several possible explanations for this inadequacy. State judges are drawn from the ranks of the very attorneys upon whom they must impose sanctions. ${ }^{44}$ In addition, present disciplinary processes may rely too heavily upon the profession itself. ${ }^{45}$ Local bar associations, which conduct disciplinary investigations and initiate disciplinary proceedings, may be less than

41. The majority opinions in the district court and the court of appeals did not discuss whether the "grave reason" standard could be applied in this manner. However, Judge Rosenn's concurrence in the court of appeals and the dissent in the district court took the position that the "grave reason" rule did not justify imposing a harsher penalty on Abrams. See 521 F.2d at 1107 (Rosenn, J., concurring); 385 F. Supp. at 1213 (Cohen, Fisher, JJ., dissenting).

Judge Adams would have remanded to the district court to give it an opportunity cither to apply the Selling-Theard test to the state suspension or to initiate an independent proceeding under D.N.J. GEN. R. 7(2)(d) \& 7(4) (described in note 42 infra). 521 F.2d at $1108-09$ \& n.10 (Adams, J., concurring and dissenting).

42. See 521 F.2d at 1104 . In addition to the "show cause" portion of its local rule, see note 36 supra, the district court is authorized to initiate independent disciplinary proceedings. D.N.J. GEN. R. $7(2)$ (d) provides for disciplinary action against any attorney "[w] ho is guilty of conduct unbecoming a member of the bar of this court." D.N.J. GeN. R. 7(4) outlines the method to be followed for procecdings under Rule 7(2)(d). It is not clear why the district court did not initiate proceedings under the relevant section of its local rule-possibly because it did not realize that its sanctioning power would be limited by the derivative posture of its "show cause" proceding.

43. The need for more effective disciplinary mechanisms has been emphasized by commentators, who have condemned the gap between "enunciated standards of performance and conduct . . . and the reality of disciplinary enforcement." Marks \& Cathcart, Discipline Within the Legal Profession: Is It Self-Regulation? 1974 U. ILL. L.F. 193,197 . In view of the size of the bar, disbarments are so infrequent as to indicate a general failure of the disciplinary process. In 1965, there were 74 federal and state disbarments; in 1973 there were 102. ABA Membership Department, Disbarment Chart 1965-1973 (on file with Yale Law Journal). For discussions of the problems of policing attorney misconduct, see ABA REPorr, supra note 3, at 121 ("problem facing the profession stems from excessive leniency"); N.Y. Times, Feb. 24, 1975, at 14, col. 3 (Chief Justice Burger, criticizing apathy of profession in policing itsclf, stated that profession has "hardly scratched the surface of the problem" of regulating and disciplining attorneys); Wash. Post, Nov. 2, 1975, at F-1, col. 6 (few disciplinary proceedings are successful); Association of the Bar of the City of New York, Ad Hoc Committec on Grievance Procedures, Report on the Grievance System 61-66 (Jan. 26, 1976) (criticizing lenient sanctioning by N.Y. Appellate Division courts).

44. See Q. Johnstone \& D. Hopson, Luwyers AND Their Work 55 (1967). For a criticism of the role of state judges in the disciplinary process, see Marks and Cathcart, supra note 43, at 202 ("[J]udges do not generally complain to disciplinary bodies about observed substandard performance.")

45. See Marks \& Cathcart, supra note 43, at 202-21 (criticizing role of local bar in disciplinary process). 
enthusiastic about actively pursuing attorneys engaging in misconduct. Given the unsatisfactory nature of state disciplinary enforcement, it is hardly in the best interests of the public to rely upon state enforcement to determine discipline in the federal courts.

The alternative to derivative federal discipline is a scheme encouraging independently-initiated proceedings by the federal courts. This alternative would enable district courts to hold attorneys to higher standards of conduct and to impose more stringent sanctions where needed. To some extent, of course, federal disciplinary enforcement is subject to the same deficiencies as that of state courts. Federal judges are also drawn from the ranks of lawyers, and some reliance on the profession in the disciplinary process is inevitable. Yet federal judges are nominated by the President, confirmed by the Senate, ${ }^{40}$ and protected by life tenure during good behavior. ${ }^{47}$ They are therefore likely to be less indebted to local centers of power. As a result, federal courts may possess greater potential for active discipline than state courts. Even if federal courts are no more effective in enforcing discipline, the creation of an independent federal disciplinary system will ensure that less misconduct goes unpunished. If the state disciplinary process fails to uncover and sanction professional improprieties, there is a chance that its federal counterpart will succeed.

It can be argued that independent initiation of federal disciplinary proceedings would be inefficient because federal courts will duplicate the efforts of state courts. But since state courts discipline very ferw attorneys-presumably far fewer than have engaged in misconduct-the duplication of effort should be minimal. Moreover, the benefits which the nonderivative policy affords to the federal courts and the public would seem to outweigh the costs of inefficiency.

Another possible objection to the suggested reform is the threat it poses to orderly relations between federal and state courts, a concern voiced by Judge Rosenn in his $A$ brams concurrence. ${ }^{48} \mathrm{~A}$ federal court which imposes a sanction more stringent than that imposed by a state court implicitly criticizes the judgment of the state court. Judge Rosenn argued that such federal action interferes with the disciplinary "province" of the states and undermines public confidence in the state courts and in the bar. ${ }^{49}$ However, public confidence in the legal

46. U.S. Const. art. II, $\S 2 ; 28$ U.S.C. $\$ 44$ (1970) (appointment of court of appeals judges); id. $\$ 133$ (Supp. IV 1974) (appointment of district court judges).

47. U.S. ConsT. art. III, $\S 1$.

48. 521 F.2d at 1105-06.

49. Id. 
profession seems to have reached a low point; ${ }^{00}$ effective federal discipline can only increase that confidence. Moreover, in actively policing: attorneys who practice before them, the federal courts are not intruding on disciplinary functions of the state courts. A greater threat to comity would arise if federal courts awaited state disciplinary action and then rejected such action as insufficient. By independently initiating their own disciplinary proceedings, the federal courts, in fact, avoid sitting in judgment on state disciplinary proceedings. ${ }^{51}$

A final argument against extensive reform of the current federal system is that there may be a simpler mode of reform: the Supreme Court could interpret Selling and Theard to allow a federal court to rely upon prior state disciplinary proceedings, but permit the federal court to diverge from the sanction imposed by the state. However, since state disciplinary action is so infrequent and inadequate, an independent federal disciplinary proceeding would be preferable to retention of the derivative system. In addition, the district courts would not have to await lengthy state deliberations that permit errant attorneys to continue practicing before federal courts. ${ }^{52}$

\section{Rationales for Federal Rules of Discipline}

The adoption of uniform federal disciplinary standards would serve two specific purposes: (1) the encouragement of independent initiation of disciplinary proceedings by the district courts and (2) consistent treatment of attorney misconduct throughout the federal system.

\section{A. Independent Initiation}

In the district courts that have no rules providing for independent initiation of federal disciplinary proceedings, ${ }^{, 3}$ federal discipline must rely almost entirely on state courts. In these districts, federal rules,

50. See, e.g., Blakeney, Should Lawyers Keep Their Monopoly? 46 N.Y.S.B.J. 100, 100 (1974) (citing a public opinion poll in which attorneys ranked I8th out of 20 professions in terms of public confidence).

51. Judge Rosenn's citation of Younger v. Harris, 401 U.S. 37 (I97I), to support his concern with comity seems misplaced. 521 F.2d at 1105 (Rosenn, J., concurring). In younger, the Supreme Court refused to enjoin a pending state criminal prosecution, fearing that an injunction would interfere with the "Iegitimate activities" of the state. 401 U.S. at 44. Yet elimination of a derivative system of attorney regulation neither prevents the state court from performing its disciplinary functions nor intrudes on any of its proceedings.

52. The ABA REPORT, supra note 3, at 158, is critical of the present situation in which attorneys are disbarred in state court, yet remain "fully eligible to walk across the street into the federal courthouse and there command the respect reserved for one entitled to the status of attorney."

53. Sce p. 978 supra. 
with explicit provision for independent initiation of disciplinary proceedings by the district courts, would undoubtedly enable those courts now without such provisions to police their bars more vigorously. Promulgation of federal rules also would reform the disciplinary processes of those district courts that already have independent initiation provisions but that still tend to defer to the states in disciplining attorneys.

The federal rules could explicitly state that independent action by the district courts is the preferred form of policing those lawyers who practice before them. Alternatively, the rules could limit the circumstances in which a federal court may rely upon prior state proceedings to cases, for example, where it becomes aware of attorney misconduct after a final determination has been made by a state court. Even then, if the court feels that the state sanction is inappropriate, it could make its own determination of the facts, apply its own disciplinary standards, and impose its own sanctions. The district court would view the prior state disposition as providing notice of purported attorney misconduct and would then institute an independent proceeding.

Promulgation of federal rules of discipline will require simultaneous development of effective enforcement procedures. That the district courts up to now have largely failed to devise such procedures militates against relying on them to find methods to enforce the federal rules. The rules themselves should designate a method of enforcement. ${ }^{5.4}$

54. The rules could place responsibility for federal discipline in the hands of the United States attorney in each district-a proposal presently before Congress. H.R. 6044, 94th Cong., 1st Sess. (1975) (authorizing federal courts to request Attorncy General to investigate charges against attorneys and United States attorney or special prosecutor to prosecute federal disciplinary proceedings). Presently, very few district courts employ the investigatory resources of the United States attorneys. Letter from Rowland F. Kirks, Director, Administrative Office of the United States Courts, to Carl Albert, Speaker of the House of Representatives (Jan. 14, 1975) (on file with Yale Law Journal); Judicial Conference of the United States, Committee on Court Administration, Report 3 (Sept. 1973) (on file with Yale Law Journal). Since it is questionable whether the United States attorneys would devote sufficient time and emphasis to discipline, Congress could require creation of a small discipline division in each United States attorncy's office, thereby ensuring some active initiation of independent disciplinary proccedings.

A second option would be to require each district court to establish an administrative office to handle discipline. Not only would this agency receive complaints from clients or other victims of attorney misconduct, but it could independently investigate reports of purported misconduct referred to it by district judges, state courts, and other sources. The administrator should be an attorney, either appointed on a permanent basis or enlisted from members of the district bar. Another possibility would be to appoint a committee of lawyers admitted to practice before the federal court to investigate and prosecute violations of professional behavioral norms, as a few districts already have done. See, e.g., S.D. CAL. R. 1.3(e)(1); D.D.C.R. 4-3 (b), (c). The district courts would have to supervise the investigations of these district committees to guard against the passive policing which has characterized state bar gricrance and disciplinary committecs. See note 43 supra. 


\section{B. Consistency in Sanctioning}

Although there is as yet no formal federal bar, ${ }^{55}$ a de facto federal bar already exists in the United States. Many attorneys are federal court specialists who deal almost exclusively with legal problems not normally handled in state courts..$^{56}$ These practitioners are retained to advise clients in complex federal specialties such as antitrust, bankruptcy, taxation, patent law, and administrative law; they appear in many different federal courts. ${ }^{57}$ Given an expanding federal practice, ${ }^{58}$ it seems reasonable to encourage consistency in the imposition of sanctions within this de facto federal bar.

That consistency does not exist under present federal disciplinary rules. The federal district courts often impose different sanctions for similar infractions. Conduct sanctionable in one district may go unpunished in another. While some courts have found tax evasion sufficient grounds for disbarment, other courts have refused to hold such

55. A proposal has been made that the Supreme Court formally establish a federal bar through the exercise of its supervisory power. Wilkey, Proposal for a "United States Bar", 58 A.B.A.J. 355 (1972). The growing body of substantive federal law and the higher level of attorney sophistication required to practice before the district courts have raised questions about the adequacy of state bar examinations to assess the federal practitioner's competence. See, e.g., Kaufman, The Court Needs a Friend in Court, 60 A.B.A.J. 175, 178 (1974); Wilkcy, supra note 10, at 1091-92. This concern has prompted suggestions for a federal bar examination and for minimum admission qualifications to federal practice. See id. at 1092 (federal bar examination); New Admission Rules Proposed for Federal District Courts, 61 A.B.A.J. 945 (1975) (description of Second Circuit's proposed rules for admission to practice before district courts); Kaufman, A Response to Objections to the Second Circuit's Proposed District Court Admission Rules, 61 A.B.A.J. 1514 (1975). Discipline, rather than admission, seems a better method of attacking the problem of incompetent attorneys. As the judges of the Eastern District of New York stated in deciding not to adopt the rules of admission proposed by the Second Circuit: "Our own observation ... has been that the instances of inadequate representation are almost always due to personal inadequacies in the lawyer or inadequate preparation of the case ...." N.Y. Times, Dec. 21, 1975, at 33, col. I (reporting statement issued by the district judges after vote to reject the proposed admission rules).

It is not necessary to establish a formal federal bar in order to discipline attorneys in nonclerivative federal disciplinary proceedings. Ordinarily, a district court admits to its bar those admitted to practice in the state in which it sits. See note 10 supra. The federal courts may retain such derivative admissions procedures. However, while both admission and disciplinary standards determine who may practice before the federal (and state) courts, the Supreme Court has recognized that the two are not linked inextricably. See p. 978-79 supra. Admission to federal practice may remain derivative while federal discipline becomes independent.

56. See Brakel \& Loh, Regulating the Multistate Practice of Law, 50 WAsH. L. Rev. 699 (1975); Note, Retaining Out-of-State Counsel: The Evolution of a Federal Right, 67 Colum. L. REv. 731 (1967); Note, Attorneys: Interstate and Federal Practice, 80 Harv. L. REv. 1711 (1967).

57. Wilkey, supra note 10 , at 1094 .

58. See Chief Justice Burger Issues Yearend Report, 62 A.B.A.J. 189, 189 (1976) (reporting 126,000 new cases filed in United States district courts in 1970, 160,602 in 1975, and predicting 180,000 for 1976 ). 
conduct sanctionable..$^{59}$ Some attorneys who have engaged in specious litigating tactics have been disbarred, while others have not. ${ }^{60}$ Similarly, while attorneys often are disbarred for fraud, some courts have been more lenient in their sanctions. ${ }^{61}$

Some of the disparity in the treatment accorded attorneys reflects differences in the disciplinary proceedings of the states in which district courts sit. ${ }^{62}$ Independent enforcement of federal discipline alone, however, would not solve the problem of inconsistent treatment of federal attorneys. The differences among existing federal rules preclude consistency in sanctioning among the districts. ${ }^{33}$

The adoption of federal rules of discipline should increase the likelihood of consistent treatment of attorneys. An analogy may be made to the Federal Rules of Evidence and of Civil and Criminal Procedure. Although designed to ensure parallel treatment for litigants rather than advocates, these procedural rules, like rules of discipline, seek to achieve uniform treatment within the same judicial system rather than allow local state practice to control. Adoption of uniform standards could enhance both the perception of fairness throughout

59. Compare, e.g., In re Bennethum, 205 F. Supp. 821, 824 (D. Del. 1962) (tax evasion demonstrated lack of moral fitness to practice law and required disbarment) with In re Teitelbaum, 253 F.2d 1 (7th Cir. 1958) (court declined to disbar an attorncy for tax evasion).

60. Compare, e.g., In re MacNeil, 266 F.2d 167, 173, 174 (Ist Cir.), cert. denied, 361 U.S. 861 (1959) (disbarment for frivolous litigation) with Quality Moulding Co. v. American Nat'l Fire Ins. Co., 287 F.2d 313, 316 (7th Cir.), cert. denied, 368 U.S. 826 (1961) (disbarment proceedings not initiated against an attorney for deliberately misquoting cases in brief).

61. Compare, e.g., Fletcher r. Laws, 64 F.2d 163 (D.C. Cir. 1933) (attorney disbarred for fraud practiced upon a client) and In re Gladstonc, 28 F. Supp. 858 (S.D.N.Y. 1939) (disbarment for conspiring to defraud client) with In re Chandler, 450 F.2d 813 (9th Cir. 1971) (court pointed out attorney fraud merited disbarment, but merely suspended her).

62. For example, some states have disbarred attorneys for misappropriation of client funds and unnecessary delay; others have imposed only short suspensions for virtually identical misconduct. Compare, e.g., In re Brown, 104 Ariz. 387, 453 P.2d 958 (1969) (state disbarment for misappropriation of client's funds and for various counts of neglect and failure to proceed) and In re Suffolk County Bar Ass'n v. La Freniere, 274 N.Y.S.2d 656, 26 App. Div. 2d 946 (1966), appeal dismissed, 19 N.Y.2d 809, 279 N.Y.S.2d 967, 226 N.E.2d 700 (1967) (state disbarment based on similar facts) with Florida Bar v. Miller, 269 So. 2d 364 (Fla. 1972) (three year suspension for conversion of client's funds and unnecessary delay) and In $r e$ Trask, 53 Hawaii 165, 488 P.2d 1167 (197I) (six-month suspension for unnecessary delay). Similarly, the states have responded rather differently to like infractions involving willful failure to file federal tax returns. Compare, e.g., In re Conley, 102 R.I. 756, 229 A.2d 847 (1967) (indefinite suspension) with State v. Cole. man, 27 Wis. 2d 282, 134 N.W.2d 89 (1965) (reprimand) and In re Anonymous No. 2, 45 App. Div. 2d 89, 357 N.Y.S.2d 506, appeal dismissed, 34 N.Y.2d 961, 359 N.Y.S.2d 1029 (1974) (no sanction).

63. Some rules, for example, require a felony conviction before disbarment or suspension, while others call for sanctions upon misdemeanor convictions. Still others discipline attorneys for noncriminal violations of the Code of Professional Responsibility. Procedural differences among the districts may also lead to disparate treatment. Sec notes 20-21 supra. 
the system and the relevance of precedent developed in other districts.

Consistency within the federal judicial system may increase the frequency of inconsistent results in state and federal disciplinary proceedings. But given the questionable disciplinary record of the states in policing attorney misconduct, ${ }^{64}$ the increased inconsistency between state and federal sanctions may well be in the public interest. Moreover, federal-state consistency is not essential, because attorneys increasingly tend to concentrate their practice in either federal or state courts. In many cities, some attorneys spend the bulk of their time practicing before federal courts, whereas the remaining attorneys have little, if any, contact with these courts. ${ }^{65}$ Not only is it likely that state courts will be far less concerned with misconduct by attorneys who do not appear before them, but there also are no established procedures by which federal courts inform the state courts of misconduct which deserves sanctioning. Professional improprieties which occur in the expanding field of multidistrict litigation ${ }^{60}$ may be even less likely to come to the attention of the appropriate state court for disciplinary action. If nothing else, it is impractical to expect state courts to regulate the federal court specialists effectively.

\section{Promulgation of Federal Rules of Discipline by the Supreme Court}

Given the abdication of responsibility for discipline by the district courts and the need for uniform rules, the Supreme Court should be the focus of any reform of federal disciplinary processes. Congress has given the Supreme Court power to promulgate rules of "practice and procedure" for the lower federal courts. ${ }^{67}$ Pursuant to this authority, the Court has promulgated Federal Rule of Appellate Procedure 46(b), which provides for suspension and disbarment of any member of the bar of a court of appeals who "has been suspended or disbarred from practice in any other court of record, or has been guilty of conduct unbecoming a member of the bar of the court." 68 To the

64. Sce note 43 supra.

65. For example, roughly $20 \%$ of New York City attorneys practice primarily before the federal courts. J. Carlin, Lawyers' Ethics-A Survey of the New York City Bar 15-16 (1966). Carlin states that "[l]awyers with an elite practice . . are most likely to be in contact with fecleral courts ...." Id . at 27 .

66. For a brief discussion of the problems concerning the growing federal multidistrict practice, see Note, Attorneys: Intcrstate and Federal Practice, supra note 56, at 1724.26.

67. 28 U.S.C. $\$ 2072$ (1970) (rules in civil actions); 18 U.S.C. $\$ \$ 3771,3772$ (1970) (rules in criminal actions).

68. Sce also Frb. R. Apr. P. 46(c) (authorizing a court of appeals to "take any appropriate disciplinary action against any attorney who practices before it for conduct un- 
extent that Rule 46(b) attempts to regulate attorney conduct outside the courtroom, it would seem to reach beyond "practice and procedure," which entails such matters as "the form of process, writs, pleadings, and motions." 69 Conceivably, the Court could promulgate federal rules of discipline under its general supervisory power over the lower federal courts. However, the Court has traditionally exercised its supervisory power in the same general area of "practice and procedure" that is covered by the congressional delegation of rulemaking authority. ${ }^{70}$

An additional grant of rulemaking authority thus may be required if the Court is to draft the desired federal rules of discipline. ${ }^{71}$ The enabling legislation for the rules of discipline, however, should not be accompanied by the requirement, found in the existing enabling statutes, that the Supreme Court report its disciplinary rules to Congress. ${ }^{72}$ Because discipline is essentially a form of judicial housecleaning, Congress should not assume responsibility for enactment of uni-

becoming a member of the bar or for failure to comply with... any rule of the court"); FED. R. CIV. P. 11 (authorizing "appropriate disciplinary action" against an attorney who willfully violates requirement that to the best of the attorney's knowledge there is good ground to support a pleading).

69. 28 U.S.C. $\$ 2072(1970)$. There is no indication in the legislative history of the enabling legislation that attorney discipline was part of "practice and procedure." See S. Rep. No. 1620, 80th Cong., 2d Sess. (1948); H.R. Rer. No. 304, 80th Cong., 1st Sess. (1947); S. Rep. No. 1049, 73d Cong., 2d Sess. (1934); H.R. Rep. No. 1829, 73d Cong., 2d Sess. (1934).

70. See, e.g., McNabb v. United States, 318 U.S. 332 (1942). For a general discussion of the scope of the Supreme Court's supervisory powers, see Note, The Supervisory Power of the Federal Courts, 76 HARv. L. REv. 1656, 1656-59 (1963).

71. If Congress fails to delegate the requisite rulemaking authority to the Supreme Court, or if the Supreme Court decides against promulgation of formal rules of discipline, the Judicial Conference of the United States could assist in implementing the reforms proposed in this Note. While the Conference has no authority to promulgate formal rules of discipline, its duties include advising on the improvement of the ad. ministration of justice in the federal courts. See 28 U.S.C. $\$ 331$ (1970). In the past, the Conference and its committees have drafted rules, leaving it to the district courts to decide whether to adopt them. See, e.g., Judicial Conference of the United States, Committee on the Operation of the Jury System, Report on the "Free Press-Fair Trial" Issue, 45 F.R.D. 391, 404-13 (1968), which recommends rules aimed at protecting criminal defendants from prejudicial publicity while preserving the right of the press to report on trials. The "Free Press-Fair Trial" rules have been subsequently adopted as formal rules by a number of district courts. See, e.g., S.D. FlA. GeN. R. 21; D.N.J. GEN. R. 36; E.D. ILI. CRIM. R. 28A (adopting rules in part). Moreover, other courts, while not formally adopting the recommendations, have relied on them in their opinions. See, e.g., United States v. Columbia Broadcasting Sys., Inc., 497 F.2d 102, 105-06 (5th Cir. 1974); Chicago Council of Lawyers v. Bauer, 371 F. Supp. 689, 692 n.4 (N.D. Ill. 1974), rev'd on other grounds, 522 F.2d 242 (7th Cir. 1975), cert. denied, 44 U.S.L.W. 3756 (U.S. 1976).

72. The enabling legislation for the rules of civil and criminal procedure provides that the rules shall not take effect until 90 days after they have been reported to Congress. 18 U.S.C. $\$ 3771$ (1970); 28 U.S.C. $\$ 2072$ (1970). Congress may extend this period to consider the rules more fully or to amend them. See Act of July 30, 1974, Pub. L. No. 93-361, 88 Stat. 397 (postponing effective date of amendments to the Federal Rules of Criminal Procedure); see also 28 U.S.C. $\$ 2076$ (Supp. IV 197.4) (providing that Federal Rules of Evidence would become effective only upon affirmative approval by Congress). 
form standards. Legislative interference with internal court affairs is unwarranted, given the judiciary's inherent power and competence to handle professional improprieties and misconduct. ${ }^{73}$ Moreover, the legislative process may impede speedy promulgation of federal rules of discipline. ${ }^{74}$ The enabling legislation therefore should provide that the federal rules of attorney discipline will take effect upon promulgation by the Court. ${ }^{\text {is }}$ Congress should limit its further involvement to appropriation of funds to ensure adequate enforcement of the rules. ${ }^{76}$

73. See Javits v. Stevens, 382 F. Supp. 131, 141 (S.D.N.Y. 1974) ("[I]t would be peculiar, if not unreasonable . . . to place responsibility for disciplining attorneys ... clsewhere than in the courts. No other body is as well qualified or as interested in determining whether an attorney is qualified to practice law."); ABA REPoRT, supra note 3 , at is (urging that courts assume responsibility for disciplinary reform); ABA Standing Committee on Professional Discipline, Recommendations 2 (Feb. 1974) (on file with Yale Law Journal) (reporting ABA House of Delegates resolution that the judiciary, not the legislative branch, should be responsible for attorney discipline). For an argument that congressional changes in the Federal Rules of Evidence were an unwise departure from a long tradition of deference to Supreme Court rulemaking, see Moore \& Bendix, Congress, Evidence and Rulemaking, 84 Y YLE L.J. 9, 11-12, $36-38$ (1974).

74. For example, after years of work by the Judicial Conference, the Federal Rules of Evidence were promulgated by the Supreme Court. Rules of Evidence for United States Courts and Magistrates, 56 F.R.D. 183 (1972). They were not adopted by Congress until two years later. Act of Jan. 2, 1975, Pub. L. No. 93-595, 88 Stat. 1926. Similarly, congressional involvement delayed the final adoption of amendments to the Federal Rules of Criminal Procedure. Act of July 30, 1974, Pub. L. No. 93-361, 88 Stat. 397 (postponing effective date to Aug. 1, 1975).

75. Cf. 18 U.S.C. $\$ 3772$ (1970) (giving Supreme Court power to prescribe rules of criminal procedure for procecdings after verdict and to fix dates when such rules shall take effect).

Even if promulgation of disciplinary rules were properly within the existing enabling legislation, the rules should be allowed to take effect automatically after being reported to Congress. See note 72 supra.

76. Sec ABA Standing Committce on Professional Discipline, Recommendations I (Feb. 1974) (on file with Yale Law Journal) (recommending federal legislation to provide funding and personnel to enforce professional discipline in the federal courts). 